\title{
El color: símbolo de poder y orden social. Apuntes para una historia de las apariencias en Europa
}

\author{
Alicia Sánchez Ortiz *
}

\begin{abstract}
RESUMEN
ABSTRACT

Olvidado por unos, ignorado por otros, el color ha sido el gran ausente de la mayoría de los discursos sobre las prácticas sociales y los juegos ideológicos. Aün por explorar, la historia antropológica de los colores constituye un vasto campo por recorrer con miradas que se abren hacia el universo material de las sociedades que nos han precedido, cuyas actividades politicas, económicas y culturales han ido entretejiendo un rico panorama que sirve como hilo conductor para aproximarnos a diferentes mundos cromáticos con sus propios códigos de sensibilidad.

Forgotten by oues, unknown by others, colour has been the big absent from the most of the studies about social practices and ideological programs. Even unexplored, anthropological history of colours constitutes a vast field to cover with open looks towards the material universe of the preceding societies whose politic, economic and cultural activities have unterweaved a rich panorama which serves us like a leading thread for an approach to the different chromatic worlds with their own codes of sensibility.
\end{abstract}

Imágenes mentales unen pensamientos portadores de sentido. Ideas que se transforman a menudo en símbolos y éstos, en ocasiones, convertidos en emblemas se muestran como signos de lectura inmediata, correspondencia legible entre una apariencia y un contenido moral. Estas imágenes simbólicas que conforman la historia y la cultura escritas por los

\footnotetext{
* Universidad Complutense de Madrid.
} 
diversos avatares de la humanidad, tan llenas de significados, han sido y continúan siendo raramente tenidas en consideración cuando se realiza una aproximación a la presencia y significados del color en el ámbito de la política, entendida ésta como el arte con que se conduce un asunto o se emplean medios para alcanzar un fin determinado.

Pero la política, como lucha de ideas, opone dos campos bien contrastados y se vale para ello de un tipo de lenguaje sencillo e inmediato. Las habituales parejas de izquierda-derecha, anarquía-orden, por citar sólo algunas, han gozado de popularidad precisamente gracias a esa simpleza; y en ese contexto, nada hay más espontáneo que la oposición entre blanco-negro, al definir dos grupos bien contrastados: negro asumido como sinónimo de oscuro y blanco como sinónimo de claro ${ }^{1}$. En términos de contraste y de parejas antagónicas, el uso político de nombres de colores es una constante en la Historia y un recurso frecuente en cualquier sistema codificado.

Con el trascurrir del tiempo, las connotaciones políticas de los colores, nacidas en la Europa occidental, se han ido internacionalizando de manera que han cubierto progresivamente un territorio cada vez más extenso. En la actualidad, es difícil tratar de explicar cualquier color sin que surja inmediatamente en nuestra mente una connotación política de él; se podría afirmar que además de esa visión sesgada sobre el simbolismo de los colores, el discurso relativo a los gustos y las elecciones cromáticas se encuentra, en cierto sentido, distorsionado por la asociación de ideas.

Todo un sistema de combinaciones de aquéllos permite a la sociedad expresar sus intenciones políticas, dinásticas, monásticas o de otro tipo. EI color, siempre y en todo, tiene una función principal centrada en clasificar, distinguir, asociar, oponer o jerarquizar. Sus múltiples juegos y contrastes posibilitan reagrupar o disociar elementos, diferenciar planos de contenido semántico diverso; en definitiva, se ofrece al hombre como medio para construir una imagen determinada de algo y dotarla de una sintaxis previamente establecida.

En una sociedad dada y abarcando un periodo más o menos amplio, se puede analizar la suma de los usos de un color, suma que constituye su campo simbólico. Ahora bien, no se debe pasar por alto que cada color tiene su propio modo de intervenir en el interior de ese campo. Cualquiera

Parece que el negro en politica ha sido utilizado en su parte negativa por adversarios de lo establecido, mientras que el blanco ha constituido un lenguaje de dos campos opuestos: tomado en su sentido positivo (por ejemplo, la bandera blanca de la monarquía con connotaciones de pureza e inccencia) o en su aspecto negativo, en términos de politica pura (el terror, la violencia perpetrada por la Contra-revolución fue llamada "Terror blanco"). 
que sea el elegido aparecerá como polisémico y totalmente ambivalente, por lo que sólo teniendo en cuenta el conjunto de las relaciones establecidas con otros un color puede ser definido, y de esa forma proceder a descifrar su significado. Para complicar aún más la aproximación a dicho elemento, lo que se ha denominado con frecuencia simbolismo de los colores está más próximo a lo emblemático que a lo simbólico; de modo que cada color es un emblema (en el sentido casi heráldico del término), de un cierto número de ideas o de conceptos personificados.

Los colores de nuestro tiempo presente tienen una larga historia y sólo pueden ser comprendidos en toda su magnitud si se analizan también aquéllos de los tiempos pasados, con los cuales han establecido hilos de continuidad y, más raramente, líneas de ruptura. Por tanto, intentar una aproximación a las prácticas y significados del color en el mundo de hoy precisa ser capaz de un retorno hacia atrás.

Bien definida por Nietzsche, en su obra La volonté de puissance, la racionalidad moderna ha decolorado el mundo y la existencia, ha llevado al hombre a creer ciegamente en la razón, sumergiéndole en una filosofía dominada por conceptos grises ${ }^{2}$. El siglo xIX asiste al triunfo de la uniformidad y se convierte en la negación política y moral de los valores expresados por el color durante siglos. Razones éticas llevaron a la sociedad industrial a teñirse con los matices definidos a través de un eje negro-gris-blanco ${ }^{3}$. El blanco, en cuanto unidad declarada de todos los colores, y el negro con su ausencia, tienden a ser puntos de referencia y de su polaridad se instaura una relación claro-oscuro que tenderá a uniformarse en tonalidades neutras a las que el ojo moderno está acostumbrado, alcanzando una agudeza visual no conocida en otras épocas. Pero, Europa, antes de llegar a esta situación, estuvo dominada por constantes cambios ideológicos que nos permiten rastrear las variaciones de sensibilidad hacia los colores. Ésta es la intención que motiva las siguientes páginas, escritas a modo de reflexión.

\section{JERARQUIA DE TINTES: UN NUEVO ORDEN CROMÁTICO}

El tinte juega un papel de primera importancia. Una gran cantidad de las materias que sirven para teñir en rojo, impregnan en profundidad las

\footnotetext{
Fragmento de 1886-1887, ed. Friedrich WüRzBACH, Paris, 1935, reeditado por Gallimard, col. Tel, 1995, vol.1, pág. 45.

Su contrario más evidente se encuentra, sin duda alguna, en la sociedad medieval, que no sólo ha amado los colores sino que ha buscado en ellos una emanación divina.
} 
fibras de las telas y resisten mucho mejor que otros colores a los efectos del tiempo. Ésta ha sido una de las principales razones por las que los colorantes de tonalidad rojiza representaron durante un amplio período al «tejido teñido" por oposición al blanco y al negro que evocaban la idea de un tejido "no teñido" ${ }^{4}$. Tanto la luminosidad como la saturación -ejes esenciales para la sensibilidad occidental hacia los colores-, habrian nacido de esta doble y antigua oposición polar entre blanco y negro (engloba todos los aspectos relativos a la luz) y entre blanco y rojo (encierra aquéllos vinculados a la densidad y a la intensidad cromáticas). De un modo general, se puede afirmar que el negro era la sombra, el rojo lo denso, y el blanco lo ambivalente, por ser a la vez lo claro y lo desaturado. Pero poco a poco esta organización del color iría cediendo en su estructura para dar paso a otro tipo de sistemas más lineales y también más jerárquicos. Surgen nuevos órdenes en los cuales cada color ocupa un lugar bien determinado.

La gran mutación de la sensibilidad cromática se produjo en el seno de la Europa feudal en el mismo momento en que se venía abajo la articulación ternaria (blanco-rojo-negro) y lograba emerger cuantitativa y cualitativamente el color azul. Precisamente, éste adquiere un valor cada vez más amplio en todos los dominios de la vida social (vestidos, emblemas...) y establece competencia con el rojo, lo que motiva tensiones que han perdurado hasta nuestro siglo materializadas en la emblemática política ${ }^{5}$. De esa manera, aunque no antes de recorrer un largo camino, el azul logró transformarse en el color de la civilización occidental. Sólo cuando la química tintorera fue capaz de fabricar una tonalidad de aquél, intensa y brillante - a partir del índigo y de la gueda ${ }^{6}$-, dicho color invadió todos los

\footnotetext{
4 Hasta las experiencias de Newton con el prisma, el blanco fue pensado como un color completo. Lo "no teñido" se situaba al lado del gris o del crudo. Lo incoloro difería completamente del blanco; en la sensibilidad occidental, aquél estaba al lado de lo transparente y por lo que concierne a los códigos sociales, se colocaba al lado del color de la piel, era el grado 0 del color.

Por ejemplo, el azul en Francia evoca la derecha republicana y liberal o los partidos del centro, pero en países vecinos puede tomar otros significados: así, en España simboliza a la Falange (extrema derecha) y a sus "camisas azules"; por su parte, el rojo ha sido utilizado como simbolo de la Revolución, del Materialismo, de la extrema izquierda, de las Internacionales Obreras, y el negro asociado a los partidos católicos conservadores y el verde a los monarquistas y más tarde a los ecologistas. Pero ¿y el amarillo? En política parece que no hay lugar para él. Su desvalorización, tanto en el plano ideológico como en el simbólico por su asociación con la traición, lo hace poco conveniente para que un movimiento político o sindical lo adopte como emblema. El tema ha sido tratado por AGIJLHON, M., "Les couleurs dans la politique française", en Ethnologie Française, $\mathrm{XX}, \mathrm{n} .^{\circ} 4,(1990)$, págs. 391-398.

6 El pastel, menos costoso al proceder de una planta cultivada en numerosas regiones, tiñó las telas de los trajes utilizados por las categorías sociales inferiores y numerosas; esto es, los campesinos. Sobre la historia del indigo y la amenaza que representaba para los productores del pastel, con las consecuencias económicas derivadas de su introducción masiva en el comercio, recomendamos la lectura de Sublime Indigo, Musée de Marseille, Éditions Vilo, París.
} 
dominios sociales, comenzando por el vestido de ceremonia, para pasar al vestido de los príncipes y terminar por ser valorizado en el resto del amplio universo social.

En este sentido, surge la cuestión de saber cuáles son las causas que ponen en marcha este proceso y con él motivan un cambio de ese tipo en la sensibilidad del hombre hacia los colores. La respuesta no es fácil, si bien parece más acertado dar prioridad a la ideología y al simbolismo sobre la química y la técnica de producción, siempre sin obviar que cualquier mutación ideológica conlleva, en mayor o menor medida, repercusiones económicas en la sociedad donde surge y se desarrolla.

Además, un nuevo orden de colores se corresponde y refleja un nuevo orden social, y esa diferente organización o estructuración de la sociedad requiere del mundo cromático la elaboración de nuevos códigos, de otros emblemas más acordes con las ideas del momento. El abandono del viejo esquema ternario y la puesta a punto de esos códigos sociales, reorganizó de manera lineal o arborescente el universo del color ${ }^{7}$ y ese orden recién establecido repercutió en todos los dominios de la vida social, material y cultural. Tras mutaciones sociales e ideológicas se encuentran profundas mutaciones de sensibilidad.

El gusto por un determinado color va ligado, a menudo, no sólo a consideraciones de tonos o de matices, sino también a cuestiones de luminosidad y de densidad. Un color dado se define por nociones de valor, esto es, por su relación con la luz y con la intensidad cromática, y de ese modo establece una jerarquia de tintes. Mejor que ningún otro, el vestido traduce perfectamente la importancia de este doble parámetro: un vestido caro se caracteriza por ser un tejido bien teñido o, expresado de otro modo, donde el color muerde en profundidad las fibras de la tela. La jerarquía de oposición se observa de manera bastante clara entre los campesinos, vestidos con colores apagados, grisáceos o descoloridos, y los príncipes, prelados y ricos patricios que brillaban con sus trajes de colores intensos, en los que los escarlatas, en su gama de tonalidades rojas y violetas, así como los azules, densos y saturados, han sido los tintes preferidos. La misma transformación se puede rastrear en el azur heráldico de los reyes de Francia que buscaron en un violeta saturado el brillo y la densidad propios de la púrpura antigua. Aquí se encuentra, en definitiva, un hecho de sensibilidad

Se trata de una nueva clasificación de los colores, no ya según estructuras de oposición o de asimilación, sino ordenados en una escala única de valores, lineal y jerárquica, del más bello a más feo, del más noble al más grosero. En este nuevo sistema, el blanco y el azul ocupan los primeros sitios, el rojo toma un lugar intermedio, y el amarillo y el negro se sitúan al final de la escala. 
fundamental que conviene resaltar: un azul saturado estaba siempre más próximo a un rojo saturado que a un azul decolorado.

De ahí la extrema importancia otorgada a las materias tintoreras, a los mordientes y a las técnicas de tinción ${ }^{8}$. Durante siglos fueron constantes los esfuerzos para lograr encontrar colorantes más saturados, más brillantes y, en definitiva, más sólidos. Cuando se alcanzaba el fin perseguido el nuevo producto pasaba a incorporarse a la lista de los ya existentes y de ese modo se establecían nuevas escalas de valores, económicas y simbólicas, que se sumaban a los precedentes, enriqueciendo en gran medida a la sensibilidad. La necesidad de emplear enormes cantidades de materias como el quermés o la cochinilla para conseguir un poco de tinte rojo determinó el elevado precio de estos dos productos y por derivación de las telas teñidas con ellos.

Un dominio aparte lo constituyen las tonalidades verdosas, dadas las grandes dificultades que Occidente encontró para obtener y fijar tintes de ese color sobre diversos soportes, incluidas las telas. Químicamente, pero también en el ámbito simbólico, el verde es un color ciertamente inestable, lo que le llevó a tener un lugar particular reservado en los sistemas simbólicos y en los códigos sociales: era el color que venía de otra parte y más que nada, el color de la transgresión. Pero el verde, además, fue símbolo de renovación, lo que explica su presencia en los vestidos de los hijos de los reyes ${ }^{9}$. El hecho de que también hayan servido para recubrir las paredes de algunas habitaciones en residencias palaciegas, propiedad sobre todo de la monarquía francesa, plantea la incertidumbre de saber si aquél pudo tener algún otro significado simbólico. Sea como fuere, el verde parece ser un color de carácter bastante privado.

De igual manera, los tintoreros fueron durante mucho tiempo incapaces de producir blancos con una gran intensidad luminosa y más todavía negros profundamente saturados. Respecto a estos últimos, hasta el siglo XV se obtenian de la agalla del roble o de la encina, asi como de la corteza o raíces del nogal, y estabail mucho más próximos a los marrones o grises, incluso a los azules, que a lo que nuestra sociedad entiende actualmente

\footnotetext{
8 Mordientes y colorantes costaban caros. Por ello, fueron frecuentes los fraudes llevados a cabo por los mercaderes que intentaban hacer pasar por duraderas las telas mal teñidas. No olvidemos que hasta la aparición de los colorantes sintéticos, el doble problema de la tintura occidental era obtener un tinte determinado y lograr fijarlo de manera perdurable en las fibras del tejido.

9 Durante todo el periodo medieval, las virtudes mágicas atribuidas al rojo (alejaba las enfermedades) y al verde (símbolo de renovación), llevaron a su empleo en las ropas que cubrian a los recién nacidos, descendientes de los reyes, así como en las paredes de la habitación donde ocurría el acontecimiento.
} 
por negro ${ }^{10}$. Su promoción en los códigos de indumentaria ocurrió a principios de los Tiempos Modernos, concretamente cuando se logro fijar ese color sobre las telas. Como en otros casos, la química, los pigmentos y el simbolismo social vuelven a estrechar sus lazos.

\section{EL COLOR PORTADO: SISTEMA DE SIGNOS}

A modo de texto, cargado de mensajes, el vestido muestra un código bien conocido por sus contemporáneos; se trata, sin duda, de una de las maneras más eficaces que la sociedad ha encontrado para plasmar los pensamientos y es obvio que dentro de este sistema el color constituye un significante de gran importancia. Su análisis permite rastrear las variaciones de la sensibilidad hacia los colores, puesto que el universo de los tejidos y de las telas pone en estrecha relación los aspectos materiales con los ideológicos, y los económicos con los estéticos. Además, se trata de un soporte en el que se encuentran las claves para responder a numerosos interrogantes acerca del color, tales como la química de los colorantes, la técnica de los tintes, los aspectos financieros, los juegos estéticos, las preocupaciones simbólicas o la organización de los códigos sociales.

En el constante juego motivado por las luchas de la apariencia, el vestido se alza en signo que ayuda a cada uno a reencontrarse, pero también constituye un elemento esencial para indicar las oposiciones sociales surgidas con los grandes acontecimientos políticos de Occidente. Como pretendemos mostrar, los mundos aristocráticos y urbanos de los Tiempos Modernos, sin abandonar totalmente su apego a los signos distintivos y exteriores, tan característicos de las sociedades feudales fuertemente jerarquizadas, se vieron arrastrados por el nuevo viento transformador, cuyo destino siguió las locuras de la moda ${ }^{11}$. Si en la sociedad antigua la afirmación de una conexión entre distinción social y diferencia en el vestir fue una constante, en el período comprendido entre el siglo XVI y el XVIII el juego se iría complicando con la puesta en marcha de varios factores, entre los que destacan el desarrollo de los grupos intermedios, la complejidad

\footnotetext{
10 Pastoureau, M., "Du bleu au noir. Éthiques et pratiques de la couleur à la fin du Moyen Age», en Médiévales, t. XIV, (1988), págs. 9-22.

11 Por otra parte, se debe tener en cuenta que la recomposición sufrida por Europa occidental y meridional durante el siglo $x \vee ı$, facilitada por los matrimonios principescos, conllevó la desaparición de las cortes con sus particularismos de modas y la indumentaria, en una Europa de Estados, menos numerosos pero también más homogéneos, tendió a afirmar el carácter nacional de cada uno de ellos. Para un estudio en profundidad del tema recomendamos Roche, D., La culture des apparences, une histoire du vêtement xir-xvire siècle, Favard, París, 1989.
} 
creciente de la civilización urbana, la divulgación de los fenómenos de imitación distintiva, las migraciones del campo a la ciudad, y la movilidad social tanto hacia lo alto como hacia lo bajo.

Dos polos permiten orientar los comportamientos y las elecciones: el vestuario fijo y el que sigue los designios de la moda. Si el primero está caracterizado por una ausencia de variaciones en el tiempo una vez perfectamente codificado, por su valor simbólico reposado sobre la perennidad, por variar bastante en el espacio definido por ámbitos nacionales, regionales, locales, o incluso familiares y cambiar de manera importante en la jerarquía social al estar casi siempre ligado a un grupo profesional, el segundo se transforma con rapidez en el tiempo y con lentitud en el espacio.

Ante todo, la moda es un hecho de sociedad. Son innumerables los testimonios que señalan su importancia cada vez mayor en los ámbitos de la corte, para más tarde extender su dominio sobre la mayoría de las clases y categorias sociales. La moda no es, por tanto, monopolio de una élite: a partir del XVIII, hay una moda lugareña y otra urbana. Apoyada sobre nociones de valor, de normas, de novedad o de cambio, por citar algunas, aquélla afecta a todos los elementos del vestido, y cómo no, al color. Pero aquí, este concepto debe ser tomado en toda su extensión y englobar los problemas de tonalidad, luminosidad y saturación. Un azul denso puede pasarse de moda coincidiendo en el tiempo con la revalorización de ese azul, en su versión desaturada.

Con anterioridad al siglo xvIII, la moda de los colores abarcaba fases de larga duración (un cuarto de siglo, la mitad de un siglo, incluso más), interrumpido por ciclos más cortos. Asi la moda de los azules en el vestido aristocrático hasta mediados del XVIII se vio perturbado por la competencia, más o menos acentuada, efimera pero recurrente de tonalidades verdes y rojas. De igual modo, entre finales del $x V$ y principios del $x V I I$, la moda del negro tuvo que convivir en el mundo de la corte con blancos, violetas, grises y rosas. Sólo a partir de mediados de 1700 , los hechos de moda se vincularian en lo sucesivo a relaciones económicas y a consideraciones ideológicas, políticas o estéticas ${ }^{12}$. Esta aceleración se vio acentuada todavía más a finales del siglo siguiente, momento en que se pone de manifiesto el uso de colores estacionales.

12 Por citar sólo un ejemplo, a partir de 1792, con la caída de la Monarquía francesa, la ideología revolucionaria encontró su forma de expresión en una indumentaria popular, reservada a los manifestantes de la calle, conocidos como los "descamisados". El traje, caracterizado por un gorro rojo, asumió un carácter ideológico y político. 


\subsection{Orden moral, orden social y regulación del parecer}

Toda indumentaria es portadora de indicaciones múltiples sobre su poseedor. Desde los ricos ornamentos de funciones supremas hasta los simples signos de reconocimiento, las distinciones positivas han sido, sin duda, buscadas con esmero por los hombres de todas las épocas. Junto a ello también se observa el deseo de marcar negativamente ciertas virtudes, adoptadas por el individuo de manera deliberada, temporal o definitivamente, dejándose llevar por un espíritu de ruptura con los valores de la sociedad, o bien como respuesta a la imposición de un orden establecido sobre determinadas categorias sociales consideradas inferiores potencialmente peligrosas para el mantenimiento del sistema.

Signos convencionales, más o menos codificados, permiten expresar un cierto número de valores y asegurar de ese modo los controles correspondientes. Cada uno debía llevar el vestido acorde con su estado y su rango. Vestirse más ricamente o más pobremente que la clase a la que uno pertenecía era considerado un sintoma de orgullo o una marca de decadencia. Se observa que el vestido tenía una clara finalidad: indicar el lugar del individuo en el seno de un grupo y el lugar de este grupo en la sociedad. Era, pues, un sistema de signos riguroso y apremiante.

Conforme nos adentramos en el período de tiempo cercano a la Baja Edad Media, aumenta considerablemente la promulgación de textos normativos y de leyes suntuarias, sobre todo en los centros urbanos, extendiéndose su campo de actuación hasta el siglo XVIII. Dichos documentos tuvieron como finalidad una triple función: moral, económica y social o ideológica.

En toda sociedad existe una moral de indumentaria que afecta a los colores. Tal vez el ejemplo más antiguo y más fuertemente codificado se encuentre en el vestido monástico cuyas normas constituyen un verdadero sistema emblemático. El negro del vestido benedictino, con una antigüedad cercana a los quince siglos, asume con plenitud el concepto de oscuro y connota una doble idea de humildad y de pobreza. Por su parte, el blanco cisterciense emerge como reacción contra el negro cluniacense. El nuevo orden se impone al antiguo; representa una búsqueda de la luz $y$ del resplandor propios de la perfección divina. $Y$ en este ambiente, el vestido de los franciscanos vendría a expresar el deseo de una pobreza absoluta y a señalar una reacción contra aquellos otros dos colores. Fabricado con un tejido burdo, el hábito franciscano es de color natural, y abarca tonalidades que van del blanco sucio al marrón oscuro, pasando por la gama de los crudos y de los grises. Representa una búsqueda del 
grado cero de color. Esta circunstancia caló hondo en la sociedad y hasta el siglo XVII los franciscanos fueron denominados "hombres grises" y San Francisco de Asís fue apodado "San Gris", una fórmula asumida en algunos juramentos, como el célebre "Vientre de San Luis", del que Rabelais y Enrique IV harian un amplio uso. Las leyes derivadas del deseo de mantener una tradición cristiana de virtud se vinculan a la gran corriente de modestia que atravesó todo el período medieval y que terminó, como se explicará más adelante, en la Reforma protestante y en la Contrarreforma.

Pero reglamentos, leyes y decretos suntuarios tuvieron motivaciones más complejas que la simple moralización de la apariencia. Buscaron limitar en todas las clases y categorias sociales los gastos concernientes al vestido y a sus accesorios, puesto que se les consideró institucionalmente improductivos. Sus prescripciones son, a veces, meticulosamente referidas a las materias primas, las telas, los precios y los colores, entre otras, pero como todos los textos normativos los decretos suntuarios representan un orden social deseado, pero seguramente no realizado, puesto que sus prescripciones fueron reiteradas sin cesar. Estas normas son un testimonio fiable de la importancia que alcanzó el vestido como marca de "status" del individuo. Ciertos colores fueron prohibidos a determinadas categorías sociales en razón de sus coloraciones demasiado inmodestas, además de por ser obtenidas mediante pigmentos apreciados, en los que el comercio y el empleo eran rigurosamente controlados.

En toda Europa, los excesos del lujo provocaron numerosas ordenanzas suntuarias tendentes a frenar el abuso o la fantasía. Se trata de reglamentaciones centradas más en poner freno al abuso de los tejidos que en ir contra las exageraciones de las formas. Las leyes suntuarias promulgadas por las autoridades de varias ciudades italianas juegan un papel en este proceso. Para mantener la distancia entre los nobles y los nuevos ricos, burgueses, con capacidad para surtir su guardarropa con la preciada seda, una de las prescripciones más recurrente es la prohibición dirigida a los no nobles con objeto de evitar que llevasen sederías de color, si bien se excluyó el negro. Ante todo, se trataba de evitar la desestabilización producida por el mimetismo social. En España, los Reyes Católicos, intentaron detener los excesos en el vestir derivados del deseo constante mostrado por algunos grupos de aparentar el prestigio de las clases sociales elevadas (nobles), plasmado a través del traje, dictando severas prohibiciones que contemplaron ciertas concesiones en el empleo de la seda. La misma distinción social, en cuanto al vestido, se repitió en la pragmática promulgada en Burgos, en 1515, extendiéndose la norma hasta el reinado de Carlos $V$, período en el que las concesiones acabaron 
por desaparecer ${ }^{13}$. La producción de tejidos sombríos se vio así acrecentada y la búsqueda de calidad fue estimulada por la demanda de dicha clientela acaudalada.

En ocasiones, los documentos a los que nos venimos refiriendo dieron prioridad a las cuestiones vinculadas al problema de la saturación sobre aquéllos relativos a la coloración. Con independencia de la categoría social a la que se perteneciese, el individuo podía adoptar prendas de cualquier color y la diferencia se establecía por medio del origen del tinte o colorante. Así, las clases campesinas podian vestir de rojo o de azul, pero éstos nunca serían el resultado de haber empleado una materia costosa, cuyo comercio estaba rigurosamente controlado por las autoridades.

También es frecuente que leyes y decretos traten antes de pigmentos y colorantes que de colores en sí mismos. Durante la primera mitad del siglo $\mathrm{XVI}$, los trajes de las clases sociales más favorecidas se caracterizaron por un rico colorido con predominio del rojo, convertida en una costumbre en algunas ciudades de Alemania. Deseoso de imitar al estamento superior, el pueblo se alzó en una revuelta para exigir el derecho de usar ropas de tonalidades rojizas. En España la situación no era muy distinta, siendo constantes las leyes dictadas por los procuradores en un intento de mantener las diferencias sociales. Una de esas normativas salió de la pragmática dictada por los procuradores de Valladolid, en 1506, en la que se solicitó la prohibición del uso de la grana a los oficiales ${ }^{14}$.

Leyes de mercado se han encargado de limitar las importaciones de materias primas costosas, y en ocasiones han pretendido evitar que los miembros de la nobleza no se viesen arrastrados hacia la ruina, como consecuencia de la adquisición desproporcionada de trajes y accesorios. Dichas normas pudieron tener su influencia en la elección de los colores y por derivación en su puesta de moda. $Y$ en este sentido es probable que el uso del negro en la indumentaria masculina española fuese reflejo de la pragmática de 1623, con la que se pretendió frenar los gastos excesivos o superfluos y en la que se ordenó el abandono de telas adornadas con polvos azules, al proceder éstos de las colonias holandesas y consecuentemente resultar carísimos.

\footnotetext{
13 Bernis, C., Indumentaria española en tiempos de Carlos V. Instituto Diego Velázquez, CSIC, Madrid, 1962, pág. 9. Para una visión de conjunto véase SemPere y Guarinos, J., Historia del luxo y de las leyes suntuarias de España, Imprenta Real, Madrid, 1788.

14 Datos obtenidos de Bernis, C., Trajes y modas en la España de los Reyes Católicos. I. Las mujeres, Instituto Diego Velázquez, Madrid, 1978, en concreto, “Leyes suntuarias y diferencias sociales en el traje", págs. 57-63.
} 
La distinción mediante el traje es fundamental en la sociedad durante el tiempo de su establecimiento. Cuando a finales del siglo XVII se hizo común la frase de que cada uno debía vestir "a su guisa", se quiso significar la necesidad de vestir según la condición del individuo. Las leyes suntuarias sivieron entonces para impedir que alguien se atreviese a jugar con su apariencia más allá de los límites del disfraz. Un clima denunciado ya por la crítica filosófica al considerar los excesos generalizados de la moda por la aristocracia como una expresión antinatural nada económica. A pesar de ello, el siglo de las Luces ignoró casi por completo las leyes suntuarias.

Este tipo de reglamentaciones invocan, bastante a menudo más que motivaciones de orden económico, la necesidad de mantener un orden social fuertemente jerarquizado ${ }^{15}$. En los grandes reinos como en las ciudades independientes, mantenidas por una aristocracia preocupada en preservar su prestigio, las leyes tendieron a señalar y a reforzar las diferencias entre las categorías: todo estaba regulado según las clases socioprofesionales: número de vestidos, piezas que los componen, tejidos, colores, etc.

Cambios ideológicos también conllevan la instauración de una segregación a través del vestido. $Y$ en este punto, no conviene olvidar que el deseo de la sociedad de identificar a ciertos miembros con unos signos especiales para humillarlos es ancestral. Los aditivos a la ropa o las prendas en si mismas constituyen un elemento apropiado para tal fin, en el que los colores significaban la señal de distinción. Cualquiera que sea la variedad de formas, diseños y colores, las marcas de las minorías sociales se rigen por ciertos principios:

a) el símbolo o ropa-símbolo, entendiendo por esto su color, su forma o ambos, debe ser completamente distinto de los que lleva la mayoría,

b) el distintivo, como accesorio o prenda, debe ser claramente visible. De ahí que se eligiesen colores brillantes que al incrementar la visualidad de los parches permitían que éstos cumpliesen su función,

c) el signo de diferenciación tiene que ser reconocido por la sociedad.

15 Ninguna reglamentación ofrece una estratificación tan detallada del mundo urbano como la de los Estatutos de Saboya, promulgados en 1430 por el duque Amadeo VIII. Los reyes y los príncipes contemporáneos debieron tener una concepción de las jerarquias sociales bastante próxima a la de aquél. Pero los Estatutos de Saboya no tuvieron como finalidad última limitar y jerarquizar las materias suntuarias, ni incluso las otras manifestaciones de lujo, sino antes bien instar a normas de la moral cristiana, denunciando las transgresiones, causa de la cólera divina, que son atribuidas a las epidemias de peste y a otros males de su tiempo. 
Es importante tener en cuenta que sin un contexto conocido, un elemento o una combinación inusual de atributos y de color en los mismos pueden no ser suficientes, impidiendo la identificación o causando graves equivocos. La abundante literatura existente sobre los colores para el vestido de los locos pone de manifiesto la gran variedad en su selección ${ }^{16}$. A menudo, se eligieron el amarillo y el verde/azul ${ }^{17}$, pero el rojo también gozó de cierta popularidad y, a veces, se recurrió a los tres combinados en las diferentes prendas de su vestido ${ }^{18}$. A los colores se deben añadir los diseños extravagantes de los tejidos.

Así pues, los colores del vestido o de ciertos elementos del mismo servían para situar inmediatamente al individuo en un determinado grupo social y al grupo dentro de la sociedad. Era el caso también de los marginados y de todas las minorías que debian portar sobre su cuerpo los signos distintivos de su infamia, cumpliendo el color entre todos ellos un papel discriminante. A pesar de la amplia gama de colores como distintivos, el amarillo y el rojo se mantuvieron vigentes durante siglos como signos denigrantes para los cristianos de "vida desordenada», tales como prostitutas, enfermos, leprosos... ${ }^{19}$, o para todos aquéllos que no pertenecian a la comunidad cristiana, como era el caso de los judíos. Dicho color no sólo fue elegido para los parches y vestidos. El Estracto de la memoria de los Estados provinciales venecianos dedicó buena parte del documento a instituir el uso del gorro amarillo a todos los judíos establecidos en ellos por considerarlo un elemento de inmediata visibilidad. El escrito comenzaba:

«... Como la cabeza es la parte más aparente del cuerpo, es también en la cabeza donde se debe poner más atención para ordenar que sea colocado el signo distintivo. Pablo IV, en su constitución del 12 de julio de 1555, ordena muy expresamente que los Judíos lleven el gorro, o sombrero amarillo asi como otra marca sobre la cabeza que no pueda ser ocultada de ninguna manera» 20 .

16 En las cortes de finales de la Edad Media y principios de los Tiempos Modernos, los niños llamados locuelos o pequeños locos llevaban vestidos de colores llamativos y a menudo abiga. rrados, como lo sugiere el nombre atribuido a la Locura "Señora de Todos los Colores".

17 En la corte de Francia, los encargados de divertir a Carlos VII, en 1459, se envolvian en vestidos que les cubrian el cuerpo hasta los pies, teñidos en su mitad blanco y en la otra verde.

18 Meli.lnkoff, R.. Outcasts: Signs of Otherness in Northern European Art of the Late Middle Ages, Calitornia, 1993, vol.l, pág. 55.

19 La enfermedad constituyó durante mucho tiempo un signo exterior de pecado. Aquéllos que la padecian eran considerados malditos y, por ello, víctimas de una absoluta discriminación social. La lepra, rara en Europa hacia finales del siglo XV, requirió de las autoridades un modo de frenar los contagios entre la población, siendo de ese modo útil el empleo de un vestido especial. En otras ocasiones, un paño blanco o rojo colocado alrededor del cuello o sobre la espalda, sirvió como signo distintivo de los enfermos de lepra.

20 Archives de Vaucluse, C.42, f.ll. Cfr. RuBENs, A., A history of Jewish costume, Londres, 1973, pág.200. 
A partir de ese momento las normativas se suceden. En un pasaje de su Teoría de los colores, Goethe muestra la herencia de la desvalorización sufrida por el amarillo durante siglos:

"Cuando el color amarillo es comunicado a superficies impuras y viles, como el paño ordinario, el fieltro, etc., donde no se presenta con toda su energia, resulta tal efecto desagradable. A raíz de una modificación leve e imperceptible la impresión hermosa del fuego y del oro se torna en una sensación francamente asquerosa y el color del honor y del deleite se trueca en el de la vergüenza, la repugnancia y el malestar" ${ }^{21}$.

El gorro amarillo y la rueda del mismo color, cosida sobre la tela del vestido, son elementos visuales a los que tanto la sociedad medieval como la postmedieval recurrirían sin cesar para marcar negativamente a la raza judía ${ }^{22}$.

En la búsqueda de un elemento que permitiese la segregación social, la raya -0 los vestidos bicromos-, fue considerada la mejor marca. Con ella se señaló a aquellos miembros que la sociedad excluía por diversas razones: ejercicio de una actividad inferior o de un oficio infame (bufones, juglares, verdugos, prostitutas...), por causa de condena (criminales), por no ser cristianos (hebreos, musulmanes, judios...), o por tener una enfermedad (leprosos, locos). De igual manera que todos ellos transgredían el orden social, sus vestidos rayados ocasionaban un desorden cromático en el vestir.

\subsection{Del negro y del blanco: al límite del sistema}

La promoción del negro a finales de la Edad Media pone de manifiesto un hecho de civilización considerable, que ha reorganizado, por varios siglos, no sólo los sistemas que rigen las maneras de vestir, sino también las teorías físicas relativas a la naturaleza de los colores.

El negro, color de moda, hizo su aparición en el vestido de los príncipes italianos a partir del siglo XIV, posiblemente como una consecuencia directa de la implantación de leyes suntuarias en Bolonia, Roma y Venecia, encargadas de prohibir, siguiendo la regla de San Bernardo, el uso de colores

\footnotetext{
GOETHE, J., Teoría de los colores, ed. Valencia, 1992, pág. 205.

A este respecto destacan los siguientes estudios: $\mathrm{KISCH}, \mathrm{G}$., "Jewery-Law in Central Europe, Past and Present", en Journal of Central European Affairs, II, (1942), págs. 410-422; KISCH, G., "The yellow badge in History", en Historia Judaica, vol.XIX, (1957), part. 2: Modern and Genuine Mediaevalism, págs. 89-146; Encyclopadeia Judaica, Jerusalén, vol.4, (1971), pág. 62 ss: "Badge. jewish".
} 
demasiado llamativos por ver en ellos el símbolo de la vanidad mundana ${ }^{23}$. La moral económica y social vuelven a unirse para promocionar un color, al igual que había ocurrido con anterioridad en el caso del rojo y después del azul.

Valorizado hasta el extremo, el negro tiñe con su presencia los ámbitos principescos durante los Tiempos Modernos. A ello contribuyó la corte ducal de Borgoña, en cuyo ámbito sólo puede ser entendida su denominación si se contemplan los intercambios desarrollados por un sistema financiero situado dentro de una estructura económica de un poder extraordinario. El insaciable deseo de igualar el lujo alcanzado por los reyes de las otras cortes, llevó a los duques a gastar elevadas sumas de dinero en su persona, lo que se materializó en la compra de tejidos teñidos en tonos violetas, azulados y negro. Se puede afirmar sin posibilidad de error que el traje negro fue en Borgoña un verdadero aliado de los duques, desde Juan "sin Miedo" hasta Renato de Anjou ${ }^{24}$.

Dicha corte codificó y catalizó todas las prácticas protocolarias a finales del período medieval para transmitírselas más tarde a la corte de España. Siguiendo esa corriente, Lucrecia de Borgia (1480-1519) mostró una marcada preferencia por la combinación de negro y oro en su guardarropa - preferencia que tal vez sea consecuencia de sus desposorios con Alfonso de Este, en 1501, y su retirada definitiva de los intereses políticos de su padre y de su hermano, cuyas intrigas la habían llevado a cometer reiterados excesos cortesanos-. Una carta de Laura Ventivoglia enviada a isabel de Este, con posterioridad al año de 1502, la describía extendida en su lecho de muerte, engalanada con un traje de seda negra ${ }^{25}$. El carácter dominante del traje español sería su sobriedad, de austera elegancia y gusto por las tonalidades oscuras, hasta tal extremo que los mismos bufones de El Escorial sustituyeron sus tradicionales colores abigarrados (amarillo, rojo, verde) por aquéllos aceptados en razón de su seriedad. Se trata de una austeridad animada a la vez por motivos económicos y religiosos. Sin tardar demasiado, la moda por el tan preciado tinte se extendió al resto de las cortes europeas; primero a Italia y más

\footnotetext{
23 Puede que la adopción de dicho color se debiese al deseo de un grupo de oponerse a los colores rutilantes de su entorno y en ese caso el suceso seria el catalizador de una tendencia en la que las premisas se unen a ciertos aspectos de la producción de tejidos.

24 Son ilustrativas las siguientes obras: CASTELLIERI, O., La cour des ducs de Bourgogne, 1946; Beaulieu M.; Bayne, J., Le costume en Bourgogne de Philippe le Hardi à Charles le Téméraire, 1956

25 Boucher, F., Historie du costume en Occident. De l'Antiquité a nos jours, Flammarion, Paris, 1965 (réed. 1983), pág. 225.
} 
tarde a Francia. Bajo el reinado de Francisco I (1515-1547), los estados de cuentas reales mencionan constantemente vestidos "a la española" ${ }^{26}$. María Estuardo (reina de Escocia desde 1542 a 1567) encargó para el luto de su marido, Francisco II, muerto en 1560, un cuerpo «a la española" de raso negro. No parece que se hayan establecido reglas de etiqueta muy estrictas, referentes al traje de duelo, con anterioridad al siglo xVI. Aunque predominaron los colores oscuros, su empleo se vería alterado con una relativa frecuencia debido a las iniciativas individuales ${ }^{27}$.

La ética de la Reforma protestante se apoderó de ese negro moralizado ${ }^{28}$. Nacida a principios de 1500 , en un período de tiempo invadido por el libro impreso y la imagen grabada - es decir en una sociedad dominada por una cultura en gris-, el Protestantismo recoge como herencia la moral del color del siglo anterior y la adapta a las necesidades del momento; son numerosos los dominios de la vida religiosa y social donde se ponen en práctica sistemas de color enteramente construidos alrededor del eje negro-gris-blanco. Por el grabado y por la estampa, utilizados con fines propagandísticos, la Reforma ha tenido una fuerte influencia sobre las mutaciones de sensibilidad en la Época Moderna, participando activamente en la revolución cultural sufrida por el mundo occidental en el período de tiempo comprendido entre los siglos $\mathrm{xV}$ al $\mathrm{XVII}{ }^{29}$. Una transformación cultural que afectó en gran medida a los códigos sociales. Es, sin duda, en el modo de vestir donde la cromofobia protestante ha ejercido su influencia más profunda y duradera, además de ser uno de los dominios donde los preceptos de los grandes reformadores han convergido, constituyendo un

26 Curiosamente, la política religiosa de este rey fue de tolerancia hacia los protestantes, tanto en sus acciones guerreras como en su manifestada simpatía por determinados humanistas de ideología reformada.

27 El duelo entraña en Occidente la costumbre de llevar vestidos negros, excepcionaimente marrones o de tonalidad azul oscura. Sin embargo, no siempre ha sido asi: el traje negro de Felipe de Borgoña (1419-1467) por la mueite de su padre, Juan "sin Miedo", puede oponerse al vestido rojo portado por Luis XI (1461-1483) en los funerales por su padre, quizá para mostrar, ante los ojos de los allí presentes, la permanencia de la realeza. De igual modo, las reinas de Francia, al convertirse en viudas adoptaban en su guardarropa velos blancos, y por esta razón han pasado a la Historia bajo la denominación de "reinas blancas". Ana de Bretaña (1488-1514) fue la primera en llevar luto negro por el fallecimiento de Carlos VIII, con quien contrajo esponsales en 1491. Sólo después del Concilio de Trento, la Iglesia tomó la decisión definitiva sobre el color de duelo.

28 Para ampliar la información sobre el papel del color en el ámbito de la Reforma protestante pueden consultarse PASTOUREAU, M., Dictionnaire des couleurs de notre temps, Éditions Bonneton, París, 1992, págs. 160-163 y "Morales de la couleur: le chromoclasme de la Réforme", en Cahiers du Léopard d'Or, 4, La couleur. Regards croisés sur la couleur du Moyen Âge au XXe siè. cle, París, (1994), págs.27-46.

29 Todas las imágenes medievales eran imágenes en color. Por contraposición, la inmensa mayoría de las imágenes ofrecidas al público en Época Moderna son imágenes en escala de grises. 
discurso casi uniforme. Puesto que la función del vestido era permitir al hombre mostrarse ante el resto de la sociedad con su alma humilde, por tanto era clara la preeminencia dada al ser sobre el parecer, aquél debía adoptar una apariencia discreta. Cualquier color intenso o saturado fue considerado deshonesto ${ }^{30}$. La guerra hacia los colores estaría centrada especialmente en los tonos cálidos, y aún más en el rojo, símbolo por excelencia del máximo lujo e imagen del pecado, y por el que Lutero y Carlstadt sintieron verdadera abominación al considerarlo emblema de la Roma papista.

De ese modo, la Reforma preparó el camino a Newton — miembro a su vez de una secta anglicana-, quien en 1666 concibió y más tarde llevó a cabo la experiencia con el prisma, cuyos resultados le permitieron excluir científicamente del orden de los colores al blanco y al negro, constituyendo éstos, ya por si mismos, un nuevo universo cromático.

Si en los paises protestantes, la ética del negro y de la sombra permaneció vigente hasta la época contemporánea, sería el siglo xVIII el encargado de reanudarla durante la Contrarreforma, participando de modo indirecto de la génesis jesuita. Un siglo después, los valores expresados por el negro se convirtieron en los del capitalismo naciente, después en los de la sociedad industrial y finalmente en aquéllo que se ha convenido en denominar, en la cultura occidental, los "valores burgueses". Lo sombrío permanece como valor en forma de un polo cromático en el vestido masculino. El burgués se reviste con las virtudes ligadas al capital y al trabajo. Apariencias que encierran un eco político extraordinario.

Al negro individual y personal del vestido se suma el efecto igualitario logrado en el ambiente urbano. La moral de la higiene y de la limpieza se impone como un efecto social en la extensión del blanco civilizador. Victoria del espíritu de la burguesía que viste y difunde la ropa blanca, aboliendo cualquier acto con carácter revolucionario. Este blanco higiénico presupone toda una filosofía pragmática. Vacuidad muda y al mismo tiempo tan llena de significado, la blancura es en su esencia al mismo tiempo la ausencia visible del color y la fusión de todos los colores. Esa blancura, símbolo de un nuevo "ethos" junto a los principios de libertad, igualdad y propiedad, es asumida por la ciudad del XIX y asimilada como un elemento social que hace posible ennoblecer a los lugares y a las personas. Sobre este blanco se entierra la memoria trágica de la colectividad y se

30 Esta cromofobia no era una guerra nueva, puesto que ya las morales del vestir medievales habian prescrito una paleta cromática similar durante varios siglos. 
plantean las nuevas esperanzas de la vida burguesa, encabezadas por la salud, el trabajo y la familia. Es un modo de expresar la oposición entre la oscuridad (el negro de la muerte, el adiós a la vida terrestre) y la luz (el blanco de lo intemporal).

\subsection{Superficie rayada-superficie codificada}

Junto al color, otro aspecto que plantea interrogantes sobre las relaciones entre lo visual y lo social se encuentra englobado en las estructuras de superficie, más concretamente en las rayas ${ }^{31}$. En este sentido no deja de resultar significante el hecho de que en Occidente, durante mucho tiempo, la mayor parte de las taxonomías sociales hayan sido prioritariamente expresadas por códigos visuales. ¿Es posible que ver siempre conlleve clasificar?

En la Época Moderna se asiste a la instauración de un nuevo orden de la raya. Sin que ninguna de sus características antiguas desaparezcan por completo, la raya adopta nuevas formas y contenidos. Su uso textil se extiende del vestido al emblema. $Y$ a su diversificación de funciones le corresponde necesariamente una diversificación de significados. De ese modo, todas las rayas no son peyorativas; al contrario, el Antiguo Régimen ve la eclosión de una "buena" raya, de una raya ensalzadora. Las rayas verticales que la Edad Media sólo había empleado con parsimonia, se multiplican y con ello, se favorece así la aparición de otros ritmos y estructuras: la estricta bicromía no ocupa ya sólo el terreno de la raya; esta última puede ser tricroma, cuadricroma, es decir polícroma.

Sobre el vestido esta variedad geométrica permite dejar atrás las antiguas clasificaciones sociales. Abandona su aspecto diabólico para estar presente en una buena parte de la sociedad adquiriendo diferentes significados. Surgen una raya aristocrática y una raya campesina, una raya festiva y una ordinaria, una exótica y una doméstica, cuyas combinaciones invaden la Europa del xVill.

Lo más característico del "status" del vestido rayado, a comienzos de los Tiempos Modernos, es el paso bastante rápido de lo diabólico a lo doméstico. Ya sea por sus antiguas connotaciones de impureza o de transgresión, las rayas se convierten poco a poco en el signo primero de una

31 Ampliamente estudiada por Pastoureau, M., Rayures. Une histoire des rayures et des tissus rayés, Éditions du Seuil, París, 1995. 
condición servil o de una función subalterna ${ }^{32}$. Cada palacio, cada corte tuvo, durante los principios del XV y la mitad del XVI, sus esclavos negros que vestían trajes con rayas. Éstas servian para expresar, a la vez, el origen pagano y la condición servil de los mismos.

Paralelamente a la raya doméstica se difunde otra categoría: se trata ahora de una raya valorizante, aristocrática, a veces mundana, siempre de buen tono, siguiendo la moda del siglo $X V \mid$ y triunfante en la segunda mitad del XVIII. El fenómeno se gestó en diversas ciudades de la Italia del Norte a finales de la Edad Media; las trusas, en las que una pierna era de un único color y la otra rayada, constituyeron no tanto una fantasía individual como una señal distintiva de sociedades cada vez más numerosas. Hacia mediados del siglo XIV, inmediatamente después de la Gran Peste, el resurgir de la alegría, tras vivir duras pruebas, llevó a los jóvenes nobles y a los ricos patricios a cometer excesos de indumentaria de todo tipo incluyendo, entre ellos, a las rayas. La idea de una transgresión del orden social y moral es en este caso más o menos fuerte. Pero esta nueva moda, en su constante enfrentamiento a las leyes y a las autoridades, no podía durar demasiado tiempo. Permaneció en la sombra durante el siguiente siglo, cuando la severa corte de Borgoña impuso a toda Europa sus valores y sus códigos protocolarios. Pero, como hemos reseñado, alrededor de principios de 1500 esta raya vertical conoció un nuevo resurgir, primero en Alemania y más tarde en Francia e Inglaterra. Los tiempos habian cambiado y las rayas modernas responden al momento. Algunos soberanos dan ejemplo y visten calzones rayados, entre ellos Francisco I y Enrique VIII. Los príncipes les imitan y de ese modo la raya vertical se vuelve aristocrática, oponiéndose a la raya horizontal que permanece en el ámbito de lo servil. Sólo la corte de España, heredera de la austeridad borgoñona, se resiste a este movimiento general. Otros factores como la Reforma protestante, las guerras, las dificultades económicas, los desordenes políticos y religiosos o la Contrarreforma católica favorecieron el retorno hacia los vestidos más estrictos y oscuros, sobre los que no había lugar para fantasias rayadas.

Sin embargo, en la primera mitad del siglo XVII las rayas hacen su aparición en la corte de España al dejar en el vestido una pequeña abertura lúdica donde aquéllas tienden a inmiscuirse, sobre todo en el traje masculino (mangas, faldones, calzas). Se trata de rayas oscuras que alternan ocres y marrones, negros y violetas, a veces verdes y oros. Una moda que duró

\footnotetext{
32 Pero no se trataba de una novedad. Ejemplos de rayas domésticas se encuentran en la Roma imperial y aún más en la época feudal. Estos primeros vestidos rayados señalaban una condición inferior, pero no necesariamente diabólica.
} 
poco y quedó reducida sólo a la aristocracia. Salvando algunas tímidas excepciones, ni el gusto francés ni el barroco italiano o alemán cultivaron los vestidos rayados.

Una situación que cambió radicalmente después de 1775 , período en que la raya vuelve a invadir el universo del vestido, de los textiles y, en definitiva, de los emblemas. Se asiste al comienzo de la raya romántica y revolucionaría ${ }^{33}$, nacida en el Nuevo Mundo, pero que encontró en el panorama de la vieja Europa un terreno particularmente fértil. Este fenómeno sí concernió a todas las clases sociales y transformó profundamente el "status" visual y cultural de las rayas y de las superficies rayadas. A finales del XVIII y principios del XIX, la ideología de la raya se había beneficiado ya de los progresos de la Revolución Industrial.

La raya moderna se fue transformando progresivamente en un instrumento más de puesta en orden ${ }^{34}$. Organiza el mundo y la sociedad, aunque ella misma permanece rebelde a toda organización demasiado rigurosa o limitada. Rebeldía y transgresión son los dominios donde debe buscarse una cierta continuidad entre las marcas medievales y el traje de los presos modernos. Del bufón al insensato, y del insensato al loco ${ }^{35}$. Se trata de la función señalética de las rayas, entendida como exclusión social, sistema que posibilita aislar a la persona del mundo exterior, un símbolo visual que se alza como obstáculo, privación de derechos o de libertad.

\section{EMBLEMAS Y SÍMBOLOS}

El vestido es siempre emblemático. Contribuye a situar a un individuo en un grupo y a este grupo en una porción de la sociedad. Pero no siempre obedece a códigos fijos y rigurosos como lo hacen ciertos sistemas de emblemas y fundamentalmente, el más gramatical de ellos: la heráldica.

\subsection{Las divisas figuradas}

La primera fuente de información sobre los colores en las cortes reales y principescas de finales de la Edad Media es la divisa. Ésta fue en la sociedad

33 Pellegrin, N., Les vêtements de la Liberté. Abécédaire des pratiques vestimentaires françaises de 1780 à 1800. Paris, 1989.

'3a La raya medieval era causa de desorden y de transgresión de las normas establecidas.

35 Foulcault, M., Surveiller et punir. Naissance de la prision, Paris, 1975; WeLSFORD, E., The Foo:. His social literary history, Londres, 1935. 
política del momento un sistema más de signos, perteneciente al dominio de la heráldica y elaborado por la nobleza en el poder. Se trataba de marcas personales que posteriormente se convertían en hereditarias y pasaban a representar a una dinastía o a una familia. La rosa blanca de Ricardo III (casa de Lancaster) y la rosa roja de sus adversarios (casa de York) finalmente se unen después de la Guerra de las Dos Rosas con la Rosa de la dinastía Tudor ${ }^{36}$. De igual manera, varios monarcas franceses recurrieron a las divisas: bajo el reinado de Carlos $V$ «el Sabio» (1364-1381), los colores reales fueron blanco y verde, pero con Carlos VII (1422-1461) se transformarían en azul-rojo-blanco; ahora bien, cuando este rey, después de la tregua de Tours (1444), quiso mostrarse como soberano de todos los franceses, abandonó aquellos colores de los años más sombríos de su reinado y adoptó la combinación de blanco-verde-rojo que había portado en sus divisas Carlos VI "el Bienamado" desde 1382 a 1422, en señal de nostalgia por los tiempos anteriores a la guerra civil. Se trató de un mensaje de reconciliación nacional comprendido inmediatamente por su pueblo.

Elegidas en relación con las preocupaciones políticas del momento y con un uso establecido a principios de cada mes de mayo, el número de colores utilizado para el fondo de cada divisa era variable, aunque en la mayoría de las utilizadas por los monarcas se jugó con una combinación de dos a cuatro ${ }^{37}$. Los factores que regían su elección podían ser razones de índole simbólica, lazos familiares, afinidades políticas, etc. Es significativo, por su rareza, encontrar en un mismo personaje un cambio total de colores, y cuando esto ocurre suele anunciar una ruptura en la vida personal (por ejemplo, una estancia en prisión) o una ambición de carácter político. La moda de este tipo de insignias llegó a tal extremo entre los príncipes ingleses que Shakespeare pudo emplearlas como un recurso más en sus tragedias, sabedor de que el sentido político que asumían sería plenamente descifrado por el gran público. Este mundo simbólico y emblemático, de ricas implicaciones en la sociedad feudal, se convirtió alrededor de 1500 en un campo sin contenido, en expresión de una antigua herencia visual. El poder había cambiado de esencia y era normal que cambiase también de formas. Aún así, este sistema persistió durante el período moderno.

\footnotetext{
36 En Inglaterra, los Lancaster llevan divisas azul y blanco, los York azul y rojo oscuro, los Tudor blanco y verde, y los Estuardo escarlata.

37 Excepciones son las divisas monocromas del Príncipe Negro o la de seis colores de Luis de Orleans. Para una aproximación a las divisas en Francia, véanse BEAUNE, C., "Costume et pouvoir en France à la fin du Moyen Âge: les devises royales vers 1400", en Revue de Sciences Humaines, LV, n. ${ }^{\circ} 183,(1981)$, págs. 125-146; MERINDOL, C., "Couleur, étoffe et politique à la tin du Moyen Âge. Les couleurs du roi et les couleurs d'une cour ducale", en Actes du $112 e$ Congrès National des Sociétés Savantes (Lyon, 1987), Éditions du CTHS, Paris, 1989, págs. 221-249.
} 


\subsection{La heráldica y el color}

Cuando a mediados del siglo XI, surgió en el norte de Francia, ésta se convirtió pronto en el gran sistema de color creado por el mundo de Occidente ${ }^{38}$. Tratar de sumergirse en su historia -incluyendo otros sistemas emblemáticos modernos (banderas, uniformes, emblemas políticos, etc)-comporta necesariamente aproximarse al aspecto simbólico de los colores ${ }^{39}$.

A comienzos de 1400, el método heráldico era ya el sistema emblemático por excelencia, conocido y utilizado en todo el ámbito europeo. La Edad Moderna no produjo transformaciones de relieve en este orden que continuó los rumbos marcados por las modificaciones experimentadas durante los dos siglos anteriores. Después de un momento de declive, localizado en la segunda mitad del XVI, la heráldica occidental se regeneró de nuevo con el arte barroco y logró prolongar su existencia durante doscientos años más. Incluso algunos países como Inglaterra, Escocia o Suiza, mantienen muy vivo este legado en sus celebraciones de carácter nacional, por no citar la formación de numerosos códigos que están en uso en nuestro simbolismo social del color, desde las banderas a los uniformes, pasando por las etiquetas de botellas de vino, los logotipos políticos, etc. ${ }^{40}$.

Insertados en el ámbito militar y eclesiástico ${ }^{41}$, los emblemas heráldicos son distintivos, colectivos o individuales que, con una peculiar estética regida por un estudiado juego de líneas nítidas y colores, brillantes y contrastados, se muestran ante nuestra mirada en una clara manifestación de riqueza, poder y fuerza.

Tanto unos como otros han estado con frecuencia sometidos en sus diseños a reglas muy rigurosas cuyo principal objetivo era lograr una correcta

38 Michel Pastoureau ha realizado importantes aportaciones al campo de la heráldica medieval. Entre sus muchos trabajos sobre el tema, pueden consultarse los siguientes: Traité d'Héraldique, (Préface de Jean Hubert), Bibliothèque de la Sauvegarde de l'Art Français, Picard, París, 1979; "L'apparition des armoiries en Occident, état du problème", en Bibliothèque de l'École des Chartres, CXXXIV, (1976), págs. 281-300; "L'origine des armoiries: un problème en voie de solution?", en Genealogica et Heraldica, Report of the 14th International Congress of Copenhague, (1982), págs. 241-254.

39 Una reflexión profunda del tema fue realizada por MENÉNDEZ-PIDAL, F., Los emblemas heráldicos. Una interpretación histórica, Discurso leido en la Real Academia de la Historia, Madrid, 1993.

40 Para un análisis de la heráldica de prestigio en nuestra sociedad actual, véase NEUBECKER, O., Le Grand Livre de l'Heraldique. L'histoire, l'art et la science du blason. Bordas, 1993, pp-262-265.

41 El mundo eclesiástico constituye otro de sus campos de actuación. Los papas llevaron durante siglos su blasón familiar, caracterizado por figuras y colores. De igual modo, la jerarquia eclesiástica se sirve de la heráldica para establecer el rango del titular. Para una visión de las insignias eclesiásticas, reproducidas en color, recomendamos la consulta de NEUBECKER, O., Op. cit., págs. 236-238. 
visibilidad del signo. Éstas fueron limitadas a unas pocas, si bien se trataba de fórmulas prescritas con fuerza que han dotado de características propias al sistema heráldico europeo si se lo compara con otras codificaciones emblemáticas anteriores o posteriores. Con mucho, la mayor originalidad del mismo reside en el empleo de un número reducido de colores (siete normalmente) y en sus estrictas combinaciones. Al tratarse de colores abstractos, intelectuales, el blasón no conoce ni matices ni diferentes tonalidades, por lo que gules, por ejemplo, puede ser bermellón, carmin o escarlata; es un rojo conceptual y su creador tiene plena libertad en la elección de su tono. Un análisis exhaustivo, en forma de tablas estadísticas sobre los colores presentes en los escudos de armas, sin duda se revelaría sumamente instructivo y permitiría aportar a la historia de la sensibilidad occidental una carga de informaciones aún desconocida que serviría sin duda alguna para resaltar ciertos problemas de gusto, de modas, de simbolismo e incluso de percepción cromática surgidos a través de los siglos y en diferentes regiones de Europa.

Con posterioridad al siglo $\mathrm{xv}$, los colores heráldicos fueron definidos con el término genérico de esmaltes, permaneciendo sin aclarar tanto las causas que originaron su aparición como las razones de su empleo ${ }^{42}$. Estos esmaltes se subdividen en dos grupos: los metales (oro y plata) y los colores rojo (gules) ${ }^{43}$, negro (sable) ${ }^{44}$, azul (azur ${ }^{45}$ y verde (sinople) ${ }^{46}$. Un séptimo color, el púrpura ${ }^{47}$, entendido como un gris violáceo, se incorporó más tarde a la lista, aunque su empleo fue bastante reducido. Razones estéticas y aún

\footnotetext{
42. Las posibles causas de este cambio terminológico han sido estudiadas por GAUTHIER, M., Émaux du Moyen Âge occidental, París, 1972, pág.17-35.

43 Remitimos a NYROP, K., "Gueules, histoire d'un mot", en Romania, t. LXVIII, (1922), págs.559-570.

44 Ese nombre no apareció en la heráldica hasta mediados del siglo XIII y estuvo con anterioridad denominado por el vocablo noir.

45 Véase, entre otros, el análisis de SCHEFFER, G.U., "Azur romantique ou scientifique? Les couleurs héraldiques, leur réhabilitation et leur détermination», en Mélanges offerts à Szabolcs de Vajay, Braga, (1971), págs. 529-536.

46 Surge a finales del siglo XI1, pero sólo en la segunda mitad del XIV sinople asumió el sentido de verde. Con probabilidad las razones de este cambio se debe a la ignorancia mostrada por algunos autores de escudos de armas o técnicos del blasón, al pretender crear un término que evitase una posible confusión entre vert y vair.

47 Hasta finales del siglo xIv el púrpura fue representado mediante un color intermedio, a menudo el gris y no, como cabria esperar, por el rojo violáceo. Dicho término apareció en el vocabulario heráldico durante el período comprendido entre 1260-1270. En el antiguo francés, el púrpura designaba una calidad de las telas y para concretar su color era precisa la adición de un adjetivo; así, los autores de la época se refieren al pourpre vermeille, pourpre noire, pourpre inde..., siendo el más frecuente el pourpre bise, que correspondia a una tela de calidad inferior. El problema planteado por el púrpura dentro del sistema heráidico ha sido analizado con rigor por PASTOUREAU, M., "Les origines du pourpre héraldique», en Cahiers d'héraldique, V, (1980).
} 
más de índole económico hicieron que el oro y la plata fuesen sustituidos en la práctica por dos colores, el amarillo y el blanco. Si gules, azur y sable han existido como colores heráldicos desde los orígenes y se han empleado con mayor frecuencia para colorear la figura que para dotar de una tonalidad al fondo, el sinople apareció un poco más tarde para ser aplicado sobre las figuras antes de serlo igualmente en los campos ${ }^{48}$, aunque su índice de empleo permaneció en clara inferioridad con respecto a los otros dos anteriormente citados.

En un blasón realizado según lo establecido, no pueden yuxtaponerse o superponerse dos colores pertenecientes al mismo grupo, por lo que siempre resulta la combinación de un metal y un color. Si las figuras son de metal, el fondo (campo) será de un color o a la inversa. Una regla esencial impone esta alternancia: se trata de evitar cualquier equivocación en la percepción visual del signo a distancia ${ }^{49}$. Aunque el origen de dicha regla permanece aún sin descifrar, una posible fuente de inspiración pudiera haber sido el método de fabricación de los escudos, según el cual la superficie exterior, de madera o pergamino, era cubierta con un color, estando recamado por debajo con metales que adoptaban diversas formas. Pero quizá también haya influido cierta norma cromática que, sin duda por razones de legibilidad, prohibía combinar el amarillo con blanco, el rojo con azul y el negro con verde ${ }^{50}$. A tenor de lo dicho, surgieron seis categorías de escudos bicromáticos: blanco/rojo, amarillo/rojo, blanco/negro, amariIlo/negro, blanco/azul y amarillo/azul. Conviene hacer notar en este punto que la normativa de uso aplicada a los colores heráldicos, lejos de responder únicamente a cuestiones de visibilidad, está basada en una doble estructura de oposición: lo claro o pálido (blanco o amarillo) y sus dos contrarios, lo brillante (rojo) y lo oscuro (negro o azul, más raramente verde).

Resulta también interesante observar como el azur fue adquiriendo cada vez más prestigio hasta llegar a convertirse en el color arquetipo de la realeza. A finales de la Edad Media y a principios de los Tiempos Modernos convivió con el rojo (gueules); después se volvió el primer color

48 En la primera mitad del siglo XIII.

49 Sin embargo, no son pocas las armerías del reino de Navarra que contravienen este principio. Gonzalez-Doria, F., Diccionario Heráldico y Nobiliario de los Reinos de España, Editorial Bitacora, Madrid, 1987. De igual modo, hay excepciones a la norma en la emblemática de las banderas, concretamente la de Alemania estaría mal construida desde el punto de vista de la heráldica, ya que las bandas negras y rojas no están separadas por el amarillo.

so A este respecto véase PaStoureau, M., "Vogue et perception des couleurs dans l'Occident médiéval: le témoignage des armoires", en Actes du 102 congrès national des sociétés savantes, Section de philologie et d'histoire, Limognes, (1977), t. II, págs.81-102. 
en el blasón de Francia, Italia e Inglaterra hasta mediados del siglo XVII ${ }^{51}$. Vista aisladamente, la historia cifrada de este azur heráldico (o de todo otro color), permanece anecdótica. Pero comparada con otros campos del ámbito social (vestido, léxico, hábitat), toma un fuerte valor documental. En el blasón se pueden observar los primeros fundamentos de una historia del gusto de las poblaciones europeas en materia de colores, historia en la que son esenciales los aspectos culturales e ideológicos.

Al azul y al rojo, colores que permitían expresar el ideal más noble, se contraponen otros colores que encerraban en sus significados la transgresión de los valores establecidos por el conjunto de la sociedad: la combinación de oro/sinople (a veces sable=negro) ha servido para tal fin. Durante un período de tiempo considerable, el amarillo y verde asociados han constituido los colores de la locura. Al igual que en otras manifestaciones culturales, la heráldica permite rastrear en sus dominios la desvalorización que el amarillo (oro) ha sufrido en la sensibilidad occidental ${ }^{52}$. Algo similar le ocurrió a otro metal, la plata, que a menudo fue representada por el blanco. A diferencia de este último color, que mantuvo todo su prestigio semántico y estético, el amarillo perdió su sentido original, dejó de ser símbolo del Sol, de la divinidad y de expresar la idea de riqueza, y pasó a convertirse en el color de la bilis, de la mentira, de la traición y de la herejía. El caso del verde es algo más sutil debido a su ambivalencia, y unido al amarillo evocaba cierta idea de perturbación ya fuese social, amorosa o mental. En el ámbito de la heráldica imaginaria, la irrupción en el relato de un caballero con escudo, caballo o indumentaria de color verde manifestaba siempre un cierto desorden producido por su comportamiento inadecuado con respecto al orden establecido.

La difusión, a partir de 1520-1530, de las imágenes mayoritariamente en blanco y negro creó graves dificultades a algunas artes o a ciertas ciencias que tenían una clara necesidad de la imagen polícroma para expresarse con plenitud. Entre ellas la heráldica, ya que si no se conocen los colores de los escudos, la información es incompleta y el riesgo de una mala lectura, interpretación o confusión es elevado. En el período comprendido entre finales del sigio xV y la mitad del xVII, se llevaron a cabo numerosos ensayos para intentar traducir los colores del blasón por medio de letras o de signos topográficos, pero durante mucho tiem-

\footnotetext{
Únicamente los germanos se resistieron a su empleo, seguramente porque el rojo, color del emperador, habia asumido desde hacia siglos la connotación de poder monárquico.

52 Entre los siglos xil-xv el empleo del amarillo-metal en el blasón no dejó de decrecer, debido más que nada a su sustitución por el amarillo-color
} 
po ninguno de los códigos creados de esa manera logró alcanzar una verdadera unificación, hecho que no se modificó hasta que el jesuita Silvestro Pietra Santa traspasó dicho horizonte en el año de 1630 al poner a punto, en Roma, un ingenioso sistema de puntos y líneas con el que se codificaron en tipografía los siete colores utilizados en los escudos. A finales del XVII este sistema alcanza un uso general en toda la Europa occidental.

Refinado hasta el extremo, el vocabulario del blasón posee un léxico preciso y numeroso para calificar y diferenciar los escudos de armas formados por cuatro estructuras de superficie diferentes: rayas horizontales (fajado), verticales (palado), oblicuas de izquierda a derecha (bandado) y oblicuas de derecha a izquierda (barrado). Las tres primeras se encuentran con frecuencia, mientras que la última es bastante rara (salvo en Italia) y precisamente por su rareza posee una cierta connotación peyorativa ${ }^{53}$. Por otra parte, existe una terminología para distinguir los rayados que resultan al recortarse sobre un plano en un cierto número de rayas o de bandas (particiones) de aquéllas que están simplemente dispuestas en un único plano (piezas). En el primer caso, el número de bandas es par, no hay más que un plano y la bicromía está perfectamente equilibrada; en el segundo, el número de bandas es impar, hay dos planos y el color dominante es el del plano del fondo. Para el blasón, las rayas verdaderas son las particiones, es decir, las que hacen fusionar en un único plano la figura y el fondo. Visualmente, es imposible determinar cuál es el color de la figura y cuál es el del fondo, lo que no deja de constituir una cierta perversión perceptiva que abre la puerta al escándalo; toda superficie rayada parece engañar, puesto que prohibe al ojo distinguir las formas de una

53 Como el antiguo manto barrado de los carmelitas, los escudos de armas de similar estructura en su superficie gozaron, durante largo tiempo, de mala reputación y se les reservó, en la heráldica literaria, para simbolizar la maldad y traición de algunos caballeros. Estos escudos de armas imaginarios rayados también sirvieron para personificar tres vicios: la inconstancia, la mentira y la astucia. Como caso excepcional, y con un significado ajeno al descrito, encontramos el escudo de armas del reino de Aragón, surgido a finales del siglo $\mathrm{x} \|$, formado por rayas verticales amarillas y rojas (GonzÁlez-DoRiA, F., Diccionario heráldico y nobiliario de los Reinos de España, ed. Bitacora, Madrid, 1987).

Estas rayas, que pudieron tener un origen provenzal, son quizás la herencia de una antigua bandera feudal, signo visual de adhesión. Constituyen un emblema prestigioso y no un símbolo despreciativo. Pero ¿cómo podía el espectador de entonces distinguir entre los escudos de armas verdaderos y los imaginarios? ¿Cómo era posible que algunos príncipes, señores o familias osaran tener un escudo de armas rayado sabiendo que en numerosos textos literarios, así como en representaciones artísticas diversas, aquellos escudos eran atribuidos a personajes perversos? ¿Es una cuestión sólo de contexto?, ¿depende del nivel de lectura?, ¿entra en juego el tipo de receptor? El código del blasón, en todo caso, se muestra en dicho contexto altamente eficaz puesto que es capaz de incorporar, sobre la misma estructura de imagen, dos sistemas de valores diferentes, cuando no opuestos. 
manera nitida. A partir de las cuatro estructuras rayadas de base, el blasón construye una infinidad de variantes, jugando con el numero y el grosor de las rayas, y sobre todo con la forma de las líneas por las cuales éstas se hallan limitadas entre sí. El sistema es infinito y el código se encuentra abierto a un sinfin de posibilidades.

Este tipo de ejercicios geométricos y lexicográficos alrededor de la raya facilita a la heráldica, apoyándose en figuras simples y fáciles de representar, no sólo dotar de escudos al conjunto de la sociedad, sino también establecer reagrupamientos. El efecto que produce en el campo perceptivo es lo suficientemente homogéneo para señalar la cohesión de la familia (todos los escudos se parecen), pero al mismo tiempo introduce diferencias que ayudan a cada uno de sus miembros a distinguirse de los demás.

\subsection{Sintaxis del color: las banderas}

Como ya se ha indicado, la organización del color en la heráldica viene a constituir el principal elemento de sintaxis en su código y ha motivado su predominio sobre la mayor parte de las otras prácticas emblemáticas en el seno de las sociedades europeas. Es en el universo de las banderas donde esta influencia dominante del blasón puede observarse con mayor nitidez. Su evolución ha sido lenta y compleja, casi siempre ligada a las transformaciones que se iban produciendo en los usos heráldicos, de modo que se puede observar en dicha emblemática un paso progresivo del dominio familiar al dinástico, del dinástico al monárquico y de éste al nacional.

Banderas rojas de peligro y prohibición, blancas de rendición, amarillas de epidemias y cuarentena, son sólo algunas de las muchas utilizadas en guerras, descubrimientos, derrotas, victorias, enfermedades y un sinfín de acontecimientos públicos que a lo largo de los siglos se han visto cubiertos por su velo emblemático. A la vez emblema y objeto simbólico, su historia ha estado sometida a continuas reglas y a rituales específicos. Construídas mediante una combinación indefinida de colores y figuras, se alzan corno la mejor representación de lo inmaterial, imagen-símbolo cuya referencia visual invoca a la Unidad. A pesar de constituir un polo esencial en el conjunto de los sistemas emblemáticos, y a diferencia de otros simbolos nacionales o emblemas de Estado, la bandera ha sido, en sus historias y en sus etnologías, poco apreciada, quizá porque la reproducción de ellas con sus colores actuales, demasiado abigarrados, tiende a agredir al ojo con una cierta vulgaridad. 
Aquélla, sin embargo, es un rico documento histórico de carácter antropológico, reflejo de acontecimientos que en nada han sido anecdóticos. Una historia concreta y raramente inmóvil -en la que economía, ideología y cultura se muestran indisociables-, envuelve la aparición de cada bandera. Dentro de ese universo, el color es un fenómeno estrechamente cultural. Los parámetros con los que se define varían de una cultura a otra y de una época a otra. No debemos olvidar que en el mundo occidental, los valores actuales para definir un color determinado (tonalidad, luminosidad y saturación) se han ido estableciendo muy lentamente ${ }^{54}$. En este sentido, percibir el color de un estandarte es un proceso que no siempre ha significado lo mismo.

Como todo signo, todo emblema, una bandera no va jamás sola; de hecho si se la percibe aisladamente, carece de significado. Sólo alcanzará un sentido pleno si aparece asociada u opuesta a otra bandera. Su origen señala con claridad este factor. La bandera deriva de las enseñas militares que permitían a los soldados identificar, en pleno combate, las unidades a las que pertenecían y distinguirlas de los enemigos. Sin embargo, a finales del siglo XVIII la situación de Europa, dividida en cinco grandes estados regidos por los Borbones (España, Francia, Nápoles, Toscana y Parma), cuyas banderas blancas se diferenciaban únicamente por los cuarteles del escudo, con la enorme confusión que esto podía acarrear en tiempos de guerra, movió a Carlos III de España a adoptar una serie de medidas dirigidas a encontrar una enseña de buena visibilidad ${ }^{55}$. Fue así como, en 1785, se eligió el diseño formado por tres franjas horizontales, de color rojo la primera y la tercera, y amarilla la del centro. El ejército la adoptó en 1843 y pasó a convertirse en símbolo nacional. Pero en el transcurrir del tiempo, los partidos republicanos la modificaron en tricolor, al sustituir la lista inferior roja por otra de color morado ${ }^{56}$.

54 Otras articulaciones, tales como seco-húmedo, blando-duro, mate-brillante, frío-cálido, sirvieron en otros momentos para definir a un color, incluso de una manera prioritaria sobre las estrictas cuestiones de coloraciones.

55 Para una información más exhaustiva sobre el tema en cuestión puede ser útil la consulta de las siguientes obras: SUÁREZ INCLAN, J., Banderas y estandartes de los cuerpos militares, Talleres del Depósito de la Guerra, Madrid, 1907; Maria de Puelles y Puelles, A., Símbolos nacionales de España, S.imp., Madrid-Cádiz, 1941, y más recientemente publicado el de Manzano Lahoz, A., Las banderas históricas del ejército español, Ministerio de Defensa, Madrid, 1996.

56 Color asociado al recuerdo de los comuneros de Castilla y empleado durante el siglo XIX por diversos grupos liberales. La presencia del mismo en la bandera española se situa en 1831 . cuando para estrechar los lazos existentes entre la Corona y el Ejército, ante las constantes intrigas de los absolutistas, la reina Maria Cristina hizo entrega de una bandera a la 1. ${ }^{a}$ Unidad de cada Arma. Dichas enseñas fueron de color morado para el Regimiento Inmemorial del Rey, de Infanteria y de Ingenieros. El primero de ellos ya la tenia desde el 14 de octubre de 1830, si bien no 
La bandera con tres colores no adquirió más que tardiamente un verdadero status oficial. Sin embargo, se encuentra su uso después de 1603, en la bandera británica, cuando Juan VI Estuardo, rey de Escocia, convertido también en rey de Inglaterra, realizó la unión personal de los dos reinos, para lo cual hizo fusionar en una sola fórmula vexilológica tricolor la bandera de Escocia, hasta entonces blanca y azul, y la de Inglaterra, roja y blanca.

Pero sería en el período revolucionario, con objeto de expresar la ideologia del pueblo, cuando se gestaron las nuevas fórmulas que permitieron su irrupción masiva en la vexilología, al alzarse en arquetipo, símbolo de la independencia y de la libertad para numerosos estados de Europa que terminaron por adoptarla como instrumento de propaganda válido para expresar ciertos valores ideológicos en pleno resurgir. Moda que tiene su punto de partida en la americanofilia de Francia y de los países hostiles a Inglaterra, surgida alrededor de 1770. La Revolución americana, con su bandera formada mediante trece rayas rojas y blancas, correspondientes a las trece colonias de América, aparece como la imagen de la Libertad. De ese modo, la raya adquirió un "status" ideológico y político: se constituyó como un medio de proclamar la anglofobia o la adhesión al movimiento de las libertades.

El origen de la bandera tricolor francesa es confuso. La escarapela ha precedido a la bandera. Con su superficie rayada, aquélla es visualmente un blanco perfecto. Se trata de una insignia en el sentido absoluto del término, la cual se convirtió en el emblema de la Guardia nacional y, por extensión, fue interpretada como la imagen de la unidad cívica del país ${ }^{57}$. No resulta fácil comprender por qué dicha divisa tricolor emergió entre el 14 y el 17 de julio de 1789 , ni cuál es el significado de sus tres colores ${ }^{58}$. La vieja explicación de que el blanco era el color del monarca y la pareja azul-rojo símbolo de la ciudad de París, no parece en la actualidad demasiado convincente porque durante mucho tiempo el rojo y el azul no fueron los colores municipales de aquella ciudad. Con bastante más acierto, y en época reciente, se ha apuntado que los tres colores habrian sido, antes de 1789, el símbolo de la revolución en marcha y por tanto expresión de la adhesión a nuevas ideas proclamadas por la misma ${ }^{59}$.

\footnotetext{
antes de reiterados intentos que se remontan al siglo XVII, mientras que el Regimiento de Reales Guardias de Infantería obtuvo su bandera morada en su moderna creación, esto es en 1830 .

Algunos han llegado a evocar mediante estos colores los tres órdenes de la nación. De hecho, la fiesta de la Federación, ceiebrada el 14 de julio de 1790 , reforzaba esta idea. A principios de la Convención se convertirian en el símbolo oficial del nuevo Régimen.

58 Sobre la interpretación de los colores resulta interesante la opinión de R. GIRARDET, "Les trois couleurs", recogido en Les Lieux de Memoire, t. I, París, 1984, págs. 5-35.

59 Tesis expuesta por Pastoureau, M., Dictionnaire des couleurs..., op. cit., pág. 34.
} 
Interesante resulta también el rico contenido de ideas que expresa la bandera roja estrechamente ligada a la historia de Francia. El rojo, símbolo de sangre pero sobre todo de la púrpura antigua, fue durante un largo período de tiempo imagen de la soberanía del poder supremo y hasta el siglo $x V I$ continuó figurando entre los atributos de la monarquia francesa. Hasta ese momento, el color rojo de la bandera significó la lucha sin piedad y cuando los enemigos la veían elevarse al frente de las tropas reales, sabían que aquélla era un claro anuncio de una batalla donde no habria prisioneros. Casi dos siglos más tarde, una ley francesa, promulgada el 20 de octubre de 1789, prescribía el despliegue de la bandera roja ante casos de revuelta callejera para anunciar la inminente proclamación de la Ley marcial y la consecuente intervención de la fuerza armada. Los levantamientos populares contra dicha ley asumieron como suya aquella bandera y la transformaron en símbolo de la insurrección revolucionaria y del movimiento obrero. En este clima social, Lamartine, a pesar de haber sido un gran defensor de los tres colores, se interesó por la bandera roja y la presentó, en 1848 , no ya como un signo de sangre o de muerte ${ }^{60}$, menos aún como una amenaza del eventual terror, sino en razón de su monocromismo como símbolo de la unidad del pueblo francés ${ }^{61}$; el rojo preferido a cualquier otro color por ser más alegre, más brillante, y en definitiva más agradable ante los ojos de la muchedumbre. Nadie entonces tenía la idea de que ese rojo fuese aquél de la sangre. Frente al rojo, el negro como emblema de la Anarquía, contrario a los valores morales establecidos.

Objeto simbólico, imagen emblemática, alegoría personificada, a la vez señal y memoria, presente, pasado y futuro, la bandera sufre todas las manipulaciones rituales de los signos con fuertes connotaciones.

\subsection{La disciplina de las apariencias: un orden establecido}

Todo aquéllo que es válido para las banderas, puede aplicarse también a los vestidos emblemáticos, englobando en este grupo uniformes e insignias de todo tipo: las libreas, los uniformes domésticos y profesionales, los vestidos jurídicos y universitarios, los hábitos monásticos y litúrgicos, los uniformes militares, etc. Su historia, inseparable de las prácticas

60 Son ilustrativos los estudios de Dommanget, M., Histoire du drapeau rouge des origines à la guerre de 1939, Librairie de l'Étoile, París, 1966 y de CONTAMinE, Ph., "Le drapeau rouge des rois de France», en L'Histoire, 61, (1983), págs. 54-63.

61 Un análisis del siglo xix en la obra de AGULHON, M., Marianne au combat. L'imagerie et la symbolique républicaine de 1789 à 1880, Flammarion, París, 1979. 
del color, se inscribe en largos períodos de tiempo. En ceremonias de la vida pública, judicial, política o religiosa, la elocuencia del vestido conserva toda su fuerza.

Orden significa ante todo regla, «status", es decir, una prescripción a la cual uno se somete libremente. Esta sumisión se muestra en público a través de insignias. Agrupamientos de ese tipo tenían como razón de ser un carácter religioso y podían volverse molestos para los diversos reinos; su capacidad militar los convertía en sospechosos ante los soberanos que, para remediar dicha situación, decidieron convertirse en creadores, ejerciendo todo el control sobre el signo. Si las órdenes de caballería tienen un origen bastante remoto, ligado a las Cruzadas, observándose su mayor influencia en el mundo renacentista donde adquirieron cada vez más énfasis y fueron consideradas vehículos de la propaganda política, junto a ellas convive un movimiento gestado en Francia. Alrededor de 1578, Enrique III, instituyó la Orden del Santo Espíritu, primera con un carácter político y, algo más tarde, en 1693, Luis XIV creó una orden de mérito bajo el vocablo de San Luis. Pero, a diferencia de las insignias de las verdaderas milicias medievales (órdenes de caballería), cruces de diferentes colores cosidas sobre los mantos, los miembros de las órdenes de corte se distinguen por una figura simbólica que cuelga de un collar formado por piezas que también encierran un significado ${ }^{62}$. Aquí el color ha perdido su primacía para dar paso a las formas.

Entre todas las instituciones, tal vez fuera la Iglesia cristiana la que reconoció, con un mayor interés de conveniencia, el valor expresivo de los colores y su efecto psicológico sobre el ánimo de los fieles ${ }^{63}$. Según la convención litúrgica, los colores siempre fueron reconocidos únicamente por su carácter dominante (blanco, rojo, verde...) y en ningún caso se cuestionó el tono o matiz de los mismos. Cada uno de ellos representaba una categoría pura, una idea abstracta, un concepto. Así, el rojo litúrgico podía traducirse en un bermellón, un carmín o un púrpura; que fuese uno u otro el elegido no tenía la menor importancia porque no aportaba ningún cambio al significado simbólico. En los tres supuestos referidos se obtenía un rojo arquetipo, es decir, el símbolo de todos los rojos.

Centro de reencuentro de las apariencias y de la disciplina social, la historia de la indumentaria militar merece un momento de nuestra atención. En sus comienzos, la tonalidad monocroma propia de la sociedad

62 Para más información NeUBECKER, O., Le Grand Livre de..., op. cit., págs. 214-215.

63 Este aspecto ha sido tratado en mi estudio «El color en la Liturgia. (Funciones, usos y simbolismo), en Ars Sacra, diciembre, 1999 (en prensa). 
civil, con mayoría campesina, fue la dominante en la indumentaria del soldado, vestido como podía y no como debía, inmerso en un mundo militar que se debatía en un fluir constante entre la inestabilidad y la permanencia, entre las guerras y la paz. A pesar de ello, referencias a vestidos uniformados de diferentes colores, usados por ciertas unidades militares, se hacen cada vez más habituales conforme nos adentramos en el siglo Xvi.

Con todo, el uniforme tiene un origen reciente, algo menos de tres siglos de existencia. Nadie duda que la Guerra de los Treinta Años constituyó la etapa decisiva para su implantación y desarrollo posterior. Algunos factores como la importante movilización de hombres y el desplazamiento del norte al sur de Europa, las oposiciones entre la religión y la nación, hicieron que esta gran guerra, a la vez civil y religiosa, necesitase de un remedio para la confusión y con objeto de ello se creó un sistema de signos distintivos. En el arte de la guerra, los colores multicolores de las tropas en una batalla campal sirven para distinguir las formaciones a los ojos del mando y, por tanto, proyectar las incursiones y los asaltos. En medio del verde de la campiña, la distinción del color militar es un aspecto más de táctica ofensiva. A la libertad que reinaba en la indumentaria del soldado se suceden entonces constantes iniciativas para alcanzar estos objetivos.

El nacimiento del uniforme en el siglo $X V||{ }^{64}$ se sitúa bajo el signo de la transformación social del Antiguo Régimen: la consolidación de la monarquía absoluta, el desarrollo de la armada y el nacimiento de la artillería moderna, son algunos de los más importantes síntomas de la búsqueda de un nuevo emblema que permita mantener el equilibrio social entre el ámbito militar y el civil. Se trata de un período marcado por el triunfo de la raya, una costumbre que venía de lejos pues ya en tiempos del reinado de Felipe "el Hermoso" resalta el empleo, por parte de las tropas, de una indumentaria de colores vistosos y de fantasía que se halla generalmente semipartida, con una media rayada y la otra de una tonalidad única ${ }^{65}$. Rayas y blasones se reúnen para crear un sistema de emblemas válido en la organización y jerarquización de grupos.

Triunfante bajo el reinado de Luis XIV, rey guerrero, se mantiene durante la época regida por Luis XVI, monarca pacífico, para volver a ser

\footnotetext{
64 Entre otras fuentes bibliográficas, pueden resultar interesante las siguientes: NoRTH, R., Uniformes militares: 1686-1918, Bruguera, Barcelona, 1972; VVAA., Uniformes militares. El ejército de Fernando VI, Ministerio de Defensa, Madrid, 1993.

65 Los Países Bajos copiaron no sólo la táctica de guerra de los suizos, sino también su uniforme militar, asumiéndolo como propio los conocidos como Landsknechte. SCHNEIDER, H., "Le costume militaire suisse du $\times \mathrm{VI}^{*}$ siècle", ter Congrès International d'Historie du Costume, 1952.
} 
objeto de debates cruciales entre civiles y militares y finalmente establecerse en signo social, eficiente señal de reconocimiento, válida para cimentar la unidad del mundo militar. Con lentitud pero sin retroceso, la revolución del uniforme da lugar a una revolución de emblemas: se convierte en signo que reagrupa a los defensores de la libertad y recuerda a los militares que los colores nacionales son su Patria. Por el conjunto y por el detalle, los uniformes propagan en Francia y después en Europa el nuevo ideal civico. El reinado de Felipe $V(1700-1724)$ marca el inicio de una legislación sobre la uniformidad en la historia del ejército español. La gran importancia otorgada en ese momento al color queda relevante al dotar a cada tercio de uno concreto para la casaca y de otro para la divisa, situada en las vueltas de las mangas de aquélla; incluso los cinco tercios provinciales fueron diferenciados a través de ese elemento ${ }^{66}$. Llevado por un cierto gusto afrancesado, el rey tomó la decisión de dotar a toda su Infantería con un mismo tipo de indumentaria, alzándose el rojo como el color predilecto para la milicia española.

Cuando en el siglo xIx, bajo el dominio de la sociedad igualitaria, la mayoría de civiles adoptó el vestido estricto y sombrío impuesto por la burguesía triunfante, los militares permanecieron fieles a una emblemática de rica policromía, y mantuvieron los juegos y combinaciones cromáticas como un elemento simbólico de su poder y de su apariencia.

El hecho de vestirse es a la vez un acto social, un modo de identificación y clasificación, un instrumento de poder y una expresión de éste último, un objeto de carácter simbólico y emblemático, en tanto que soporte privilegiado por medio del color. El vestido está siempre cargado de significados múltiples, pero es ante todo un medio de comunicación que sobrepasa a la palabra, inmediatamente comprensible por la mirada, en un contexto dado, propio a cada época y a cada civilización.

Medible, normalizado, el color puede cumplir funciones que en otro tiempo le estuvieron prohibidas. No sólo puede clasificar, distinguir o jerarquizar, también puede hacerse el dueño de la carne, y ser expresión plena de la apariencia del alma abandonada a los placeres del cuerpo. Idea que se haria esencial durante todo el Siglo de las Luces y que más tarde retomaría Hegel. ¡El color es carnal!. Un nuevo camino se traza para la historia de los colores en Occidente, cuya ordenación ya no se construye alrededor de seis colores de base - tal y como había sido lo habitual

${ }^{66}$ Encarnados Viejos (Madrid), Azules Viejos (Toledo), Amarillos Viejos (Burgos), Verdes Viejos (Valladolid) y Morados Viejos (Sevilla). 
desde la Antigüedad hasta la Edad Media-, sino en una escala lineal donde adquieren prioridad el rojo, el azul y el amarillo. No sólo el blanco y el negro se ven excluidos de esa clasificación del color, sino que el verde considerado como producto resultante de la mezcla entre azul y amarillo -algo por otra parte impensable en las sociedades antiguas-, es descendido en su puesto dentro de la jerarquía cromática.

La Modernidad encuentra en la liberalización del color uno de sus articulos de fe. Tal vez nuestra sociedad, en ese gusto desmedido por lo polícromo, característico de su progreso y civilización, esté cada vez más próxima a lo que Wilhelm Wundt ha denominado el gusto del alma primitiva por el estado arcaico. 